\title{
Synthesis of Functionalized Carboranes as Potential Anticancer and BNCT Agents
}

\author{
Venkata Jaganmohan Reddy, $\dagger$ Matthew M. Roforth, $\ddagger$ Chalet Tan, $* \ddagger$ M. Venkat Ram Reddy, ${ }^{*} \dagger \neq$ \\ Department of Chemistry and Biochemistry, and Department of Pharmacy Practice \\ and Pharmaceutical Sciences, University of Minnesota Duluth, Chem 233, 1039 \\ University Drive Duluth 55812 MN \\ †tvmereddy@d.umn.edu
}

Table of Contents

$\begin{array}{ll}\text { Content } & \text { Page Numbers } \\ \text { Experimental } & 2-8 \\ \text { Spectra } & 9-36\end{array}$




\section{Experimental}

General Methods. All operations were carried out under an inert atmosphere. The ${ }^{1} \mathrm{H}$ and ${ }^{13} \mathrm{C}$ NMR spectra were plotted on a Varian Gemini-300 spectrometer. Mass spectra were recorded using a Hewlett-Packard 5989B mass spectrometer/5890 series II gas chromatograph or a Finnigan mass spectrometer model 4000.

Materials: Anhydrous ethyl ether $\left(\mathrm{Et}_{2} \mathrm{O}\right)$ purchased from Mallinckrodt, Inc. was used as received. $\mathrm{CH}_{2} \mathrm{Cl}_{2}$ was distilled over $\mathrm{CaH}_{2}$. $O$-carborane was purchased from GFS Chemicals and methyl magnesium bromide, $p$-methylbenzenethiol were obtained from the Aldrich Chemical Company.

Synthesis of alcohol 3a: To a stirred mixture of methyl acrylate (1.3 mL, $14.5 \mathrm{mmol})$ and aldehyde $1(1.0 \mathrm{~g}, 5.78 \mathrm{mmol})$ was added DABCO (600 mg, $5.36 \mathrm{mmol})$. The reaction mixture was stirred overnight and worked up with $10 \% \mathrm{HCl}$ and ethyl acetate (3 x $50 \mathrm{~mL}$ ). The combined organic layers were dried over anhydrous sodium sulfate and the solvent was evaporated using a rotary evaporator. The crude product was purified on a silica gel column using hexanes and ethyl acetate (17:3) as eluents. Yield: $70 \%$. White solid, mp 99-102 ${ }^{\circ} \mathrm{C} .{ }^{1} \mathrm{H}$ NMR $\left(\mathrm{CDCl}_{3}, 300 \mathrm{MHz}\right): \delta$ 1.00-3.60 (br m, 10H), 3.86 (s, 3H), 4.07 (br s, 1H), 4.81-4.92 (dd, $J=9.6,15.3 \mathrm{~Hz}, 2 \mathrm{H}), 5.89(\mathrm{~s}, 1 \mathrm{H}), 6.44(\mathrm{~s}, 1 \mathrm{H}) ;{ }^{13} \mathrm{C} \mathrm{NMR}$ $\left(\mathrm{CDCl}_{3}, 75 \mathrm{MHz}\right): \delta 29.9,52.7,58.7,75.0,130.9,135.7,167.1 ;{ }^{11} \mathrm{~B} \mathrm{NMR}\left(\mathrm{CDCl}_{3}\right):-1.5,-$ 3.0, -8.2, -9.7, -12.3, -13.3, -14.0, -15.1; IR (KBr, $\left.\mathrm{cm}^{-1}\right)$ 1086, 1199, 1292, 1706, 2597,

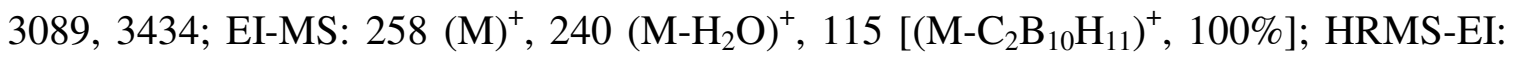
$\mathrm{m} / \mathrm{z}$ for $\mathrm{C}_{7} \mathrm{H}_{18} \mathrm{~B}_{10} \mathrm{O}_{3}$, Calculated: 260.2186, Observed: 260.2204 . 
Synthesis of meta carboranyl alcohol 4: Procedure similar to that of 3a. Yield: 70\%. White solid mp 91-96 ${ }^{\circ} \mathrm{C} .{ }^{1} \mathrm{H}$ NMR (500MHz, $\left.\mathrm{CDCl}_{3}\right): \delta 1.00-3.59(\mathrm{~m}, 10 \mathrm{H}), 3.86(\mathrm{~s}$, $3 \mathrm{H}), 4.50(\mathrm{dd}, J=9.5 \mathrm{~Hz}, 1 \mathrm{H}), 4.61(\mathrm{~d}, J=10.0 \mathrm{~Hz}, 1 \mathrm{H}), 5.76(\mathrm{~s}, 1 \mathrm{H}), 6.35(\mathrm{~s}, 1 \mathrm{H}),{ }^{13} \mathrm{C}$ NMR $\left(125 \mathrm{MHz}, \mathrm{CDCl}_{3}\right): \delta 29.9,52.6,55.1,75.1,130.0,137.4,167.2 ; \mathrm{IR}\left(\mathrm{KBr}, \mathrm{cm}^{-1}\right)$ 1076, 1187, 1287, 1700, 2577, 3069, 3384; ESI-MS: $281(\mathrm{M}+\mathrm{Na})^{+}$, HRMS-ESI: m/z for $\mathrm{C}_{7} \mathrm{H}_{18} \mathrm{~B}_{10} \mathrm{O}_{3} \mathrm{Na}$ Calculated: 281.2157; Observed: 281.2146.

Synthesis of alcohol 3b: Procedure similar to that of 3a. Yield: 75\%. White solid mp 89-93 ${ }^{\circ} \mathrm{C} .{ }^{1} \mathrm{H}$ NMR $\left(\mathrm{CDCl}_{3}, 500 \mathrm{MHz}\right): \delta 1.00-3.60$ (br m, 10H), $1.36(\mathrm{t}, J=7.1 \mathrm{~Hz}, 3 \mathrm{H})$, $4.31(\mathrm{~m}, 2 \mathrm{H}), 4.88(\mathrm{~d}, J=9.8 \mathrm{~Hz}, 1 \mathrm{H}), 4.95(\mathrm{~d}, J=9.8 \mathrm{~Hz}, 1 \mathrm{H}), 5.84(\mathrm{~s}, 1 \mathrm{H}), 6.41(\mathrm{~s}, 1 \mathrm{H})$; ${ }^{13} \mathrm{C}$ NMR $\left(125 \mathrm{MHz}, \mathrm{CDCl}_{3}\right): \delta 14.2,57.9,62.2,75.4,130.9,136.0,166.9 ;{ }^{11} \mathrm{~B}$ NMR $\left(\mathrm{CDCl}_{3}\right):-1.5,-3.0,-8.2,-9.7,-12.3,-13.3,-14.0,-15.1 ; \mathrm{IR}\left(\mathrm{KBr}, \mathrm{cm}^{-1}\right) 1088,1199$, 1291, 1702, 2581, 3078, 3390; CI-MS: $271\left(\mathrm{M}^{+}, 100 \%\right)$, HRMS-CI: m/z for $\mathrm{C}_{8} \mathrm{H}_{20} \mathrm{~B}_{10} \mathrm{O}_{3}$ Calculated: 271.2452; Observed: 271.2331.

Synthesis of alcohol 3c: Procedure similar to that of 3a. Yield: 71\%. White solid mp 96-99 ${ }^{\circ} \mathrm{C} .{ }^{1} \mathrm{H}$ NMR $\left(\mathrm{CDCl}_{3}, 500 \mathrm{MHz}\right): \delta 1.00-3.60(\mathrm{~m}, 10 \mathrm{H}), 4.03$ (br s, $\left.1 \mathrm{H}\right), 4.80(\mathrm{~d}, J=$ $9.5 \mathrm{~Hz}, 1 \mathrm{H}), 4.90(\mathrm{~d}, J=9.5 \mathrm{~Hz}, 1 \mathrm{H}), 5.27(\mathrm{~s}, 2 \mathrm{H}), 5.88(\mathrm{~s}, 1 \mathrm{H}), 6.45(\mathrm{~s}, 1 \mathrm{H}), 7.39(\mathrm{~m}$, $5 \mathrm{H}) ;{ }^{13} \mathrm{CNMR}\left(\mathrm{CDCl}_{3}, 125 \mathrm{MHz}\right): \delta 29.0,58.0,67.8,75.1,128.7,129.0,129.1,131.2$, 134.9, 136.1, 166.7; ${ }^{11} \mathrm{~B}$ NMR $\left(\mathrm{CDCl}_{3}\right):-1.6,-3.2,-4.9,-8.2,-8.7,-9.7,-10.3,-11.4,-12.6,-$ 14.1; IR (KBr, $\left.\mathrm{cm}^{-1}\right)$ 1089, 1197, 1290, 1701, 2579, 3066, 3394; CI-MS: 333 (100\%), HRMS-CI: m/z for $\mathrm{C}_{13} \mathrm{H}_{22} \mathrm{~B}_{10} \mathrm{O}_{3}$ Calculated: 333.2536, Observed: $333.2512\left(\mathrm{M}^{+}\right)$.

Synthesis of alcohol 3d: Procedure similar to that of 3a. Yield: $60 \%$. ${ }^{1} \mathrm{H}$ NMR $\left(\mathrm{CDCl}_{3}, 500 \mathrm{MHz}\right): \delta 1.00-3.60(\mathrm{~m}, 10 \mathrm{H}), 4.06(\mathrm{br} \mathrm{s}, 1 \mathrm{H}), 4.45(\mathrm{~d}, J=9.27 \mathrm{~Hz}, 1 \mathrm{H}), 5.00$ $(\mathrm{d}, J=9.3 \mathrm{~Hz}, 1 \mathrm{H}), 6.09(\mathrm{~s}, 1 \mathrm{H}), 6.71(\mathrm{~s}, 1 \mathrm{H}), 7.11-7.45(\mathrm{~m}, 5 \mathrm{H}) ;{ }^{13} \mathrm{CNMR}\left(\mathrm{CDCl}_{3}, 125\right.$ 
$\mathrm{MHz}): \delta 18.0,58.2,74.5,121.5,126.9,130.0,132.3,136.29,150.0,165.4 ;{ }^{11} \mathrm{~B}$ NMR $\left(\mathrm{CDCl}_{3}\right):-1.8,-3.2,-4.7,-8.4,-9.2,-12.6,14.0 ; \mathrm{IR}\left(\mathrm{KBr}, \mathrm{cm}^{-1}\right)$ 1086, 1190, 1288, 1703, $2590,3079,3388$.

Synthesis of alcohol 3e: To a stirred mixture of acrolein $(56 \mathrm{mg}, 1 \mathrm{mmol})$ and aldehyde $1(86.5 \mathrm{mg}, 0.5 \mathrm{mmols})$ in $4.0 \mathrm{~mL}$ of THF at $0{ }^{\circ} \mathrm{C}$ was added DABCO $(17.3 \mathrm{mg}$, 0.15 mmols). The reaction mixture was stirred for $2 \mathrm{~h}$ at the same temperature and worked up with $10 \% \mathrm{HCl}$ and ethyl acetate $(3 \times 50 \mathrm{~mL})$. The combined organic layers were dried over anhydrous sodium sulfate and the solvent was evaporated using a rotary evaporator. The crude product was purified on a silica gel column using hexanes and ethyl acetate as eluents (83:17). Yield: $60 \%$. ${ }^{1} \mathrm{H}$ NMR $\left(\mathrm{CDCl}_{3}, 300 \mathrm{MHz}\right) \delta 1.00-3.60$ (br m, 10H), 4.08 (br s, 1H), 4.25 (d, $J=9.0 \mathrm{~Hz}, 1 \mathrm{H}), 4.98(\mathrm{~d}, J=8.4 \mathrm{~Hz}, 1 \mathrm{H}), 6.33$ (s, 1H), $6.51(\mathrm{~s}, 1 \mathrm{H}), 9.58(\mathrm{~s}, 1 \mathrm{H}) ;{ }^{13} \mathrm{C} \mathrm{NMR}\left(125 \mathrm{MHz}, \mathrm{CDCl}_{3}\right): \delta 29.90,58.26,73.18,138.93$, 145.49, 194.62; IR $\left(\mathrm{KBr}, \mathrm{cm}^{-1}\right)$ 1665, 2582, 3020, 3403; EI-MS: $228[\mathrm{M}]^{+}, 210(\mathrm{M}-$ $\left.\mathrm{H}_{2} \mathrm{O}\right)^{+}, 72(100 \%)$.

Synthesis of acetate of alcohol 3f: To a stirred mixture of methyl vinyl ketone $(0.18 \mathrm{~g}$, $2.5 \mathrm{mmol}$ ) and aldehyde 1 (173 $\mathrm{mg}, 1.0 \mathrm{mmols})$ in $2 \mathrm{~mL}$ of THF at $0{ }^{\circ} \mathrm{C}$ was added DABCO (34.6 mg, $0.3 \mathrm{mmols})$. The reaction mixture was stirred for $6 \mathrm{~h}$ at the same temperature and worked up with $10 \% \mathrm{HCl}$ and ethyl acetate $(3 \times 50 \mathrm{~mL})$. The combined organic layers were dried over anhydrous sodium sulfate and the solvent was evaporated using a rotary evaporator. The crude product was acetylated with acetic anhydride and $\operatorname{Mg}\left(\mathrm{ClO}_{4}\right)_{2}$ and purified on a silica gel column using hexanes and ethyl acetate as eluents (92:08). Yield: $63 \%$ (overall yield for the two steps starting from the aldehyde 1). ${ }^{1} \mathrm{H}$ NMR $\left(\mathrm{CDCl}_{3}, 300 \mathrm{MHz}\right) \delta 1.00-3.60$ (br m, 10H), 2.08 (s, 3H), 2.34 (s, 3H), $6.10(\mathrm{~s}, 1 \mathrm{H})$, 
$6.21(\mathrm{~s}, 1 \mathrm{H}), 6.29(\mathrm{~s}, 1 \mathrm{H}) ;{ }^{13} \mathrm{CNMR}\left(\mathrm{CDCl}_{3}, 75 \mathrm{MHz}\right) \delta 20.5,25.3,30.0,60.0,68.0,128.5$, 142.9, 168.0, 197.1; IR (KBr, cm $\left.{ }^{-1}\right)$ 1056, 1188, 1702, 1755, 2589, 3012.

Synthesis of alcohol 3g: Procedure similar to that of 3e. Yield: $81 \% .{ }^{1} \mathrm{H}$ NMR (500MHz, $\left.\mathrm{CDCl}_{3}\right): \delta 1.00-3.60(\mathrm{~m}, 10 \mathrm{H}), 4.08(\mathrm{br} \mathrm{s}, 1 \mathrm{H}), 4.10(\mathrm{~d}, J=8.8 \mathrm{~Hz}, 1 \mathrm{H}), 4.61$ $(\mathrm{q}, J=8.1 \mathrm{~Hz}, 2 \mathrm{H}), 5.00(\mathrm{~s}, J=8.8 \mathrm{~Hz}, 1 \mathrm{H}), 6.08(\mathrm{~s}, 1 \mathrm{H}), 6.58(\mathrm{~s}, 1 \mathrm{H}) ;{ }^{13} \mathrm{C} \mathrm{NMR}$ (125MHz, $\mathrm{CDCl}_{3}$ ): $\delta 29.9,58.4,61.0$ (quartet), 73.5, 122.8 (quartet), 132.6, 135.9, 164.7;

${ }^{11} \mathrm{~B}$ NMR $\left(\mathrm{CDCl}_{3}\right)$ : -1.8, -3.2, -4.7, -8.4, -9.2, -12.6, -14.0; LRMS-ESI: 349.3 (100\%); HRMS-ESI: m/z for $\mathrm{C}_{8} \mathrm{H}_{17} \mathrm{~B}_{10} \mathrm{O}_{3} \mathrm{~F}_{3} \mathrm{Na}$ Calculated: 349.2031; Observed: 349.1929

Synthesis of alcohol 3h: To a stirred mixture of acrylonitrile $(160 \mathrm{mg}, 3.0 \mathrm{mmol})$ and aldehyde 1 (173 mg, $1.0 \mathrm{mmol})$ was added DABCO (34.6 mg, $0.3 \mathrm{mmol})$. The reaction mixture was stirred for $2 \mathrm{~h}$ and worked up with $10 \% \mathrm{HCl}$ and ethyl acetate $(3 \times 50 \mathrm{~mL})$. The combined organic layers were dried over anhydrous sodium sulfate and the solvent was evaporated using a rotary evaporator. The crude product was purified on a silica gel column using hexanes and ethyl acetate as eluents (17:3). Yield: $90 \%$. ${ }^{1} \mathrm{H}$ NMR $\left(\mathrm{CDCl}_{3}, 300 \mathrm{MHz}\right): \delta$ 1.00-3.40 (br m, 10H), $4.10(\mathrm{~m}, 2 \mathrm{H}), 4.81(\mathrm{~m}, 1 \mathrm{H}), 6.12(\mathrm{~s}, 1 \mathrm{H})$, $6.24(\mathrm{~s}, 1 \mathrm{H}) ;{ }^{13} \mathrm{CNMR}\left(\mathrm{CDCl}_{3}, 75 \mathrm{MHz}\right): \delta 29.9,58.5,72.6,115.7,122.8,134.9 ; \mathrm{IR}(\mathrm{KBr}$,

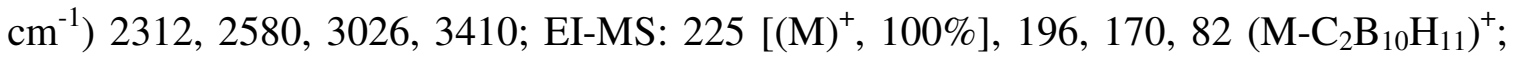
HRMS (EI): m/z for $\mathrm{C}_{6} \mathrm{H}_{15} \mathrm{NB}_{10} \mathrm{O}$ Calculated: 227.2084 Observed: 227.2100.

Synthesis of alcohol 3i: To a stirred suspension of NMO (460 mg, $4.0 \mathrm{mmol})$ in anhydrous THF $(10 \mathrm{~mL})$ was added DIBAL-H (1M solution in hexanes) $(3.0 \mathrm{~mL}, 3$ mmol) at $0{ }^{\circ} \mathrm{C}$ and the mixture stirred for $0.5 \mathrm{~h}$. Methyl phenylpropiolate $(324 \mathrm{mg}, 2$ mmol) was added and the reaction mixture stirred at $0{ }^{\circ} \mathrm{C}$ for $1 \mathrm{~h}$ followed by the addition of carborane aldehyde $(415 \mathrm{mg}, 2.4 \mathrm{mmol})$ dissolved in anhydrous THF $(2.0 \mathrm{~mL})$. The 
mixture was warmed to room temperature, stirred for $4 \mathrm{~h}$ and quenched with $3.0 \mathrm{~mL}$ of $4 \mathrm{~N} \mathrm{HCl}$, and the product was extracted with ether $(3 \times 20 \mathrm{~mL})$. The combined ether layers were washed with saturated brine and dried over anhydrous $\mathrm{Na}_{2} \mathrm{SO}_{4}$. Removal of solvent and purification by column chromatography over silica gel using hexanes and ethyl acetate (83:17) afforded pure alcohol 3i. Yield : 65\%. ${ }^{1} \mathrm{H}$ NMR (500MHz, $\left.\mathrm{CDCl}_{3}\right)$ $\delta$ 1.00-3.60 (m, 10H), $3.68(\mathrm{~s}, 3 \mathrm{H}), 4.19(\mathrm{br} \mathrm{s}, 1 \mathrm{H}), 4.85(\mathrm{~d}, J=10 \mathrm{~Hz}, 1 \mathrm{H}), 5.01(\mathrm{~d}, J=$ $7.0 \mathrm{~Hz}, 1 \mathrm{H}), 7.10(\mathrm{~s}, 1 \mathrm{H}), 7.20-7.39(\mathrm{~m}, 5 \mathrm{H}) ;{ }^{13} \mathrm{C} \mathrm{NMR}\left(125 \mathrm{MHz}, \mathrm{CDCl}_{3}\right): \delta 29.2,52.4$, $58.7,76.4,128.3,128.4,128.5,129.5,134.5,142.5,168.9$.

Synthesis of acetate 6: To a stirred mixture of alcohol 2 (750 mg, $2.9 \mathrm{mmol})$ and acetic anhydride $(0.44 \mathrm{~g}, 4.34 \mathrm{mmol})$ at room temperature was added $\mathrm{Mg}\left(\mathrm{ClO}_{4}\right)_{2}(75 \mathrm{mg}$, $10 \mathrm{wt} \%)$. The reaction mixture was stirred for $0.5 \mathrm{~h}$ at the same temperature and worked up with saturated sodium bicarbonate and ethyl acetate $(3 \times 50 \mathrm{~mL})$. The combined organic layers were dried over anhydrous sodium sulfate and the solvent was evaporated using a rotary evaporator. The crude product was purified on a silica gel column using hexanes and ethyl acetate as eluents (19:1). Yield: $90 \%$. White solid mp $130-132{ }^{\circ} \mathrm{C} .{ }^{1} \mathrm{H}$ NMR $\left(\mathrm{CDCl}_{3}, 300 \mathrm{MHz}\right) \delta 1.00-3.60(\mathrm{br} \mathrm{m}, 10 \mathrm{H}), 2.16(\mathrm{~s}, 3 \mathrm{H}), 3.83(\mathrm{~s}, 3 \mathrm{H}), 5.99(\mathrm{~s}, 1 \mathrm{H})$, $6.22(\mathrm{~s}, 1 \mathrm{H}), 6.54(\mathrm{~s}, 1 \mathrm{H}) ;{ }^{13} \mathrm{C} \mathrm{NMR}\left(125 \mathrm{MHz}, \mathrm{CDCl}_{3}\right): \delta 20.4,29.9,52.5,59.9,70.0$, 129.0, 138.0, 165.1, 168.0; IR (KBr, $\left.\mathrm{cm}^{-1}\right)$ 1045, 1212, 1284, 1731, 1758, 2587, 3016; $1.5,-3.0,-8.2,-9.7,-12.3,-13.3,-14.0,-15.1$.

Synthesis of $\boldsymbol{\alpha}, \boldsymbol{\beta}$-unsaturated ester 7: To a stirred mixture of acetate $\mathbf{6}(150 \mathrm{mg}, 0.5$ mmol) in anhydrous ether was added $\mathrm{MeMgBr}(3 \mathrm{M}$ solution in ether, $0.22 \mathrm{~mL}, 0.65$ mmol) at $0^{\circ} \mathrm{C}$ and the reaction mixture was stirred for $2 \mathrm{~h}$ at the same temperature and worked up with saturated $\mathrm{NH}_{4} \mathrm{Cl}$ and ether $(3 \times 50 \mathrm{~mL})$. The combined organic layers 
were dried over anhydrous sodium sulfate and the solvent was evaporated using a rotary evaporator. The crude product was purified on a silica gel column using hexanes and ethyl acetate as eluents (94:06). Yield: $78 \%$. ${ }^{1} \mathrm{H}$ NMR $\left(\mathrm{CDCl}_{3}, 300 \mathrm{MHz}\right): \delta 1.00-3.60$ (br m, 10H), $1.07(\mathrm{t}, J=7.1 \mathrm{~Hz}, 3 \mathrm{H}), 2.62(\mathrm{q}, J=7.2 \mathrm{~Hz}, 2 \mathrm{H}), 3.79(\mathrm{~s}, 3 \mathrm{H}), 6.58(\mathrm{~s}, 1 \mathrm{H})$; ${ }^{13} \mathrm{C}$ NMR (75 MHz, $\left.\mathrm{CDCl}_{3}\right): \delta 13.75,19.86,52.86,62.68,71.81,131.81,141.33,167.14 ;$

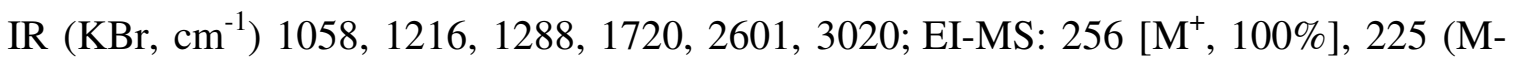
$\left.\mathrm{OCH}_{3}\right)^{+}, 113\left(\mathrm{M}-\mathrm{C}_{2} \mathrm{~B}_{10} \mathrm{H}_{11}\right)^{+}$; HRMS-EI: m/z for $\mathrm{C}_{8} \mathrm{H}_{20} \mathrm{~B}_{10} \mathrm{O}_{2}$ Calculated: 258.2394, Observed: 258.2415 .

Synthesis of thioether 8: To a stirred mixture of acetate $6(75 \mathrm{mg}, 0.25 \mathrm{mmol})$ in anhydrous $\mathrm{CH}_{2} \mathrm{Cl}_{2}$ was added p-methyl thiophenol $(30.5 \mathrm{mg}, 0.25 \mathrm{mmol})$ at $\mathrm{RT}$ and the reaction was stirred for $18 \mathrm{~h}$ at the same temperature and worked up with water and ether ( $3 \times 50 \mathrm{~mL}$ ). The combined organic layers were dried over anhydrous sodium sulfate and the solvent was evaporated using a rotary evaporator. The crude product was purified on a silica gel column using hexanes and ethyl acetate as eluents (93:07). Yield: $80 \%$. ${ }^{1} \mathrm{H}$ NMR ( $\left.\mathrm{CDCl}_{3}, 300 \mathrm{MHz}\right): \delta 1.00-3.60(\mathrm{br} \mathrm{m}, 10 \mathrm{H}), 2.35$ (s, 3H), 3.73 (s, 3H), $3.90(\mathrm{~s}, 2 \mathrm{H})$ $6.61(\mathrm{~s}, 1 \mathrm{H}) 7.15(\mathrm{~d}, J=7.8 \mathrm{~Hz}, 2 \mathrm{H}), 7.35(\mathrm{~d}, J=8.1 \mathrm{~Hz}, 2 \mathrm{H}) ;{ }^{13} \mathrm{C} \mathrm{NMR}\left(\mathrm{CDCl}_{3}\right.$, 75MHz): $\delta 21.3,31.9,53.1,61.8,70.9,130.3,133.2,133.4,134.0,135.4,139.0,166.6$;

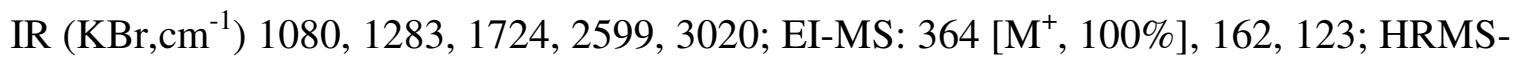
EI: $\mathrm{m} / \mathrm{z}$ for $\mathrm{C}_{14} \mathrm{H}_{24} \mathrm{~B}_{10} \mathrm{SO}_{2}$ Calculated: 365.2349 , Observed: 365.2498 .

Synthesis of amino acid 10: To a stirred mixture of glycine imine 9 ( $0.1 \mathrm{~g}, 0.34$ mmol) in anhydrous THF was added ${ }^{n} \mathrm{BuLi}$ in hexanes $(0.15 \mathrm{~mL}, 2.5 \mathrm{M}$ in hexanes, 0.37 mmol) at $-78{ }^{\circ} \mathrm{C}$ was and the reaction mixture was stirred for one hour at the same temperature and acetate 6 (102 $\mathrm{mg}, 0.34 \mathrm{mmol})$ in $2 \mathrm{~mL}$ of anhydrous THF was added. 
The reaction was stirred for additional two hours and worked up with water and ethyl acetate $(3 \times 50 \mathrm{~mL})$. The combined organic layers were dried over anhydrous sodium sulfate and the solvent was evaporated using a rotary evaporator. The crude product was taken in $2 \mathrm{~N} \mathrm{HCl}(10 \mathrm{~mL})$ solution and stirred for overnight at room temperature .The reaction mixture was washed with excess of DCM $(4 \times 50 \mathrm{~mL})$ and the aqueous layer was evaporated at $40^{\circ} \mathrm{C}$ under high vacuum to yield the product as $\mathrm{HCl}$ salt. Yield: $69 \%$. White solid mp 158-161 ${ }^{\circ} \mathrm{C} .{ }^{1} \mathrm{H}$ NMR $\left(\mathrm{CDCl}_{3}, 500 \mathrm{MHz}\right): \delta 1.00-3.60$ (br m, 10H), 2.99$3.38(\mathrm{~m}, 2 \mathrm{H}), 3.67(\mathrm{~s}, 3 \mathrm{H}), 4.09-4.12(\mathrm{~m}, 1 \mathrm{H}), 6.96(\mathrm{~s}, 1 \mathrm{H}),{ }^{13} \mathrm{C} \mathrm{NMR}\left(\mathrm{CDCl}_{3}, 75 \mathrm{MHz}\right): \delta$ , 33.8, 39.7,52.7, 60.9, 82.1, 131.2, 138.7, 169.4, 172.9; ${ }^{11} \mathrm{~B} \mathrm{NMR}\left(\mathrm{CDCl}_{3}\right):-1.5,-3.0$, 8.2, -9.7, -12.3, -13.3, -14.0, -15.1; IR (KBr, $\left.\mathrm{cm}^{-1}\right) 1045,1154,1278,1689,1718,2578$, 2981, 3300(br). 
Compound 3a

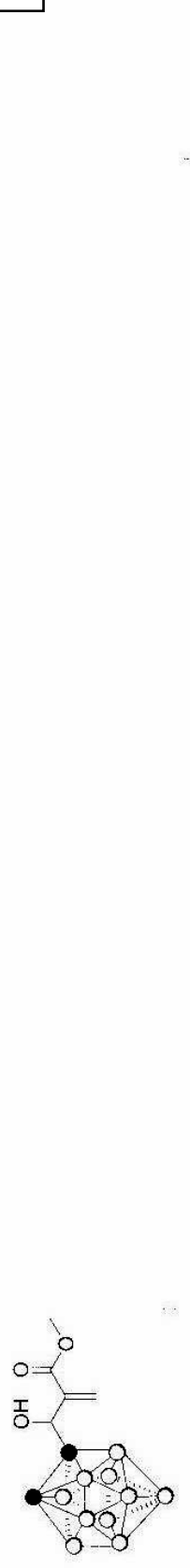

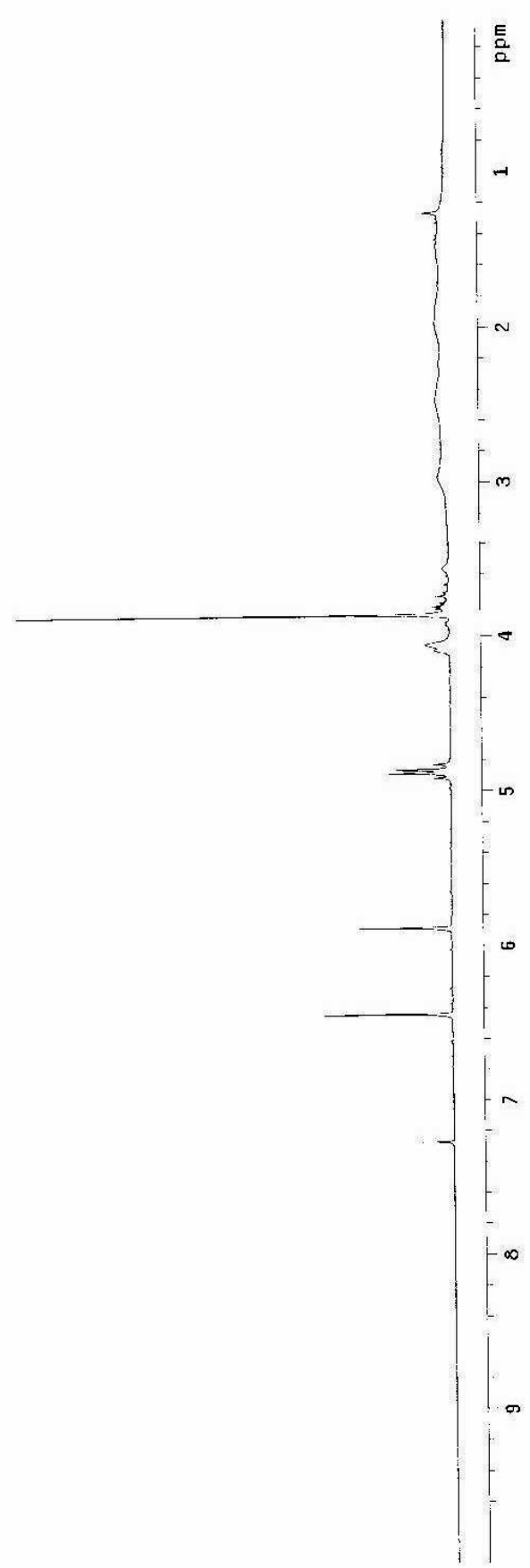




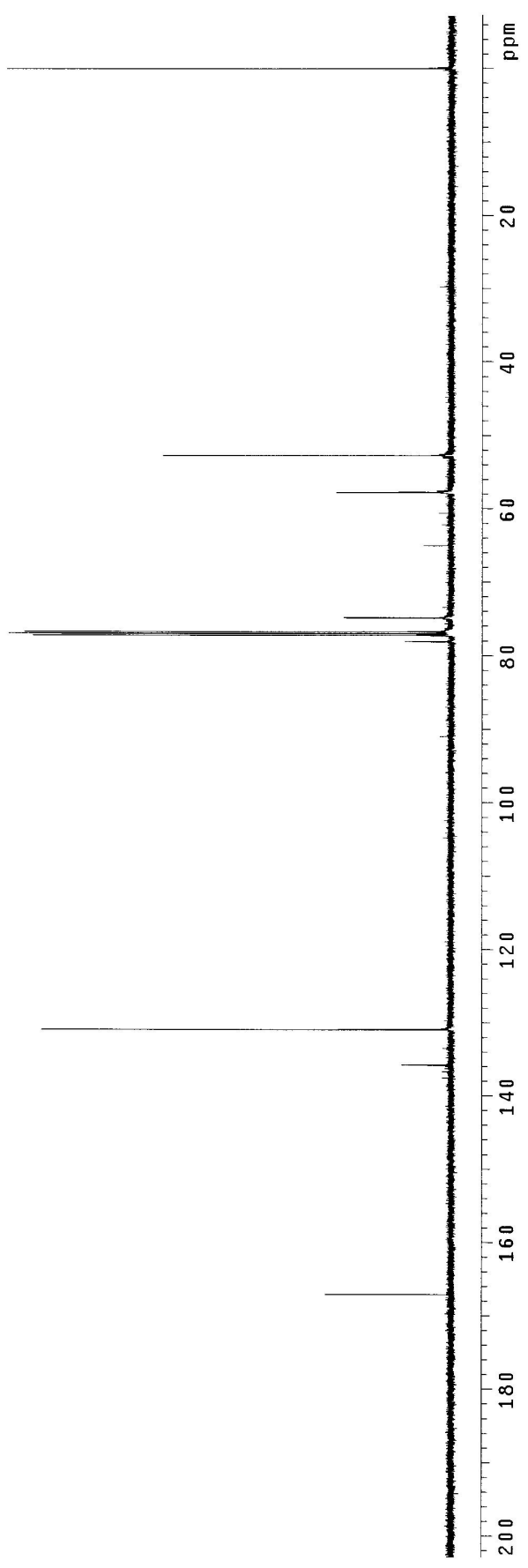




\section{Compound 4}

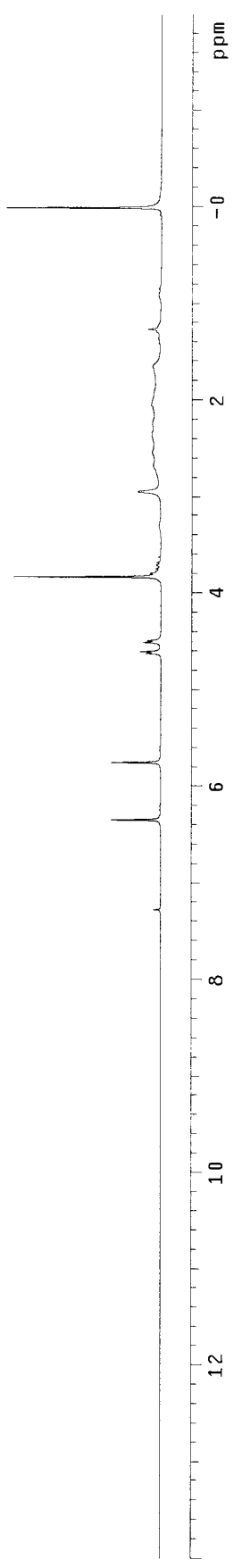




\section{Compound 4}

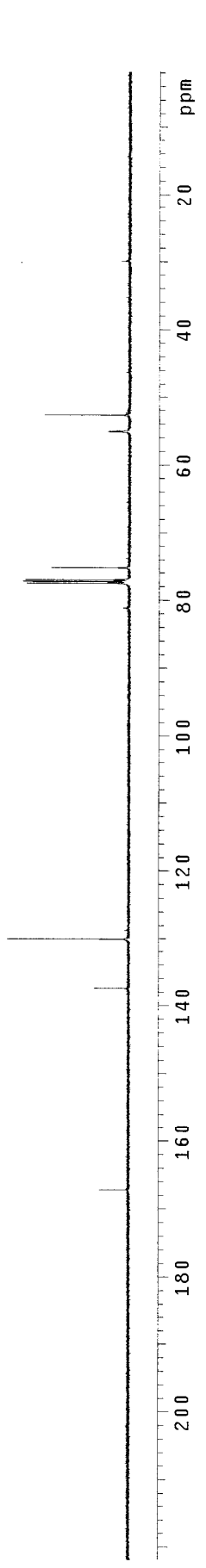




\section{Compound $3 b$}

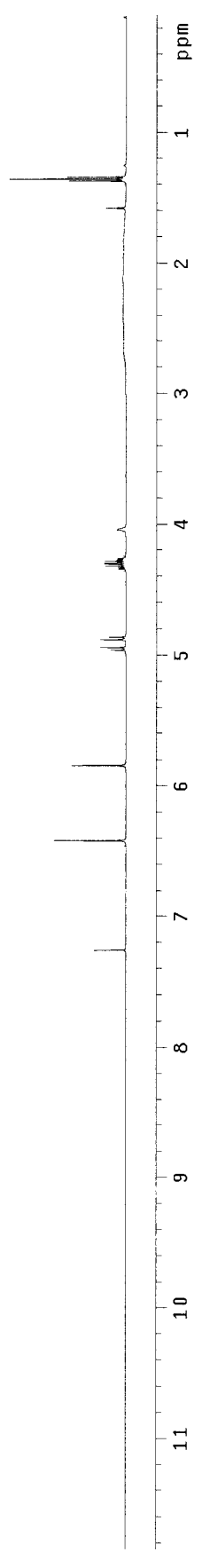


Compound $3 b$

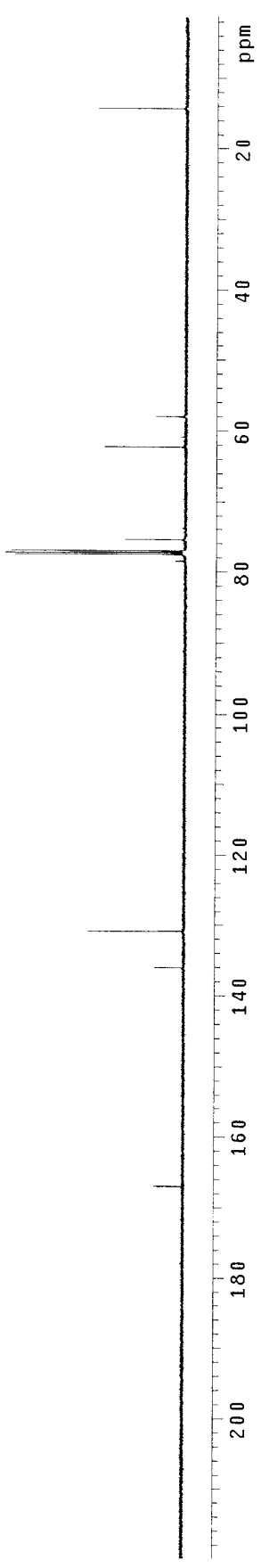




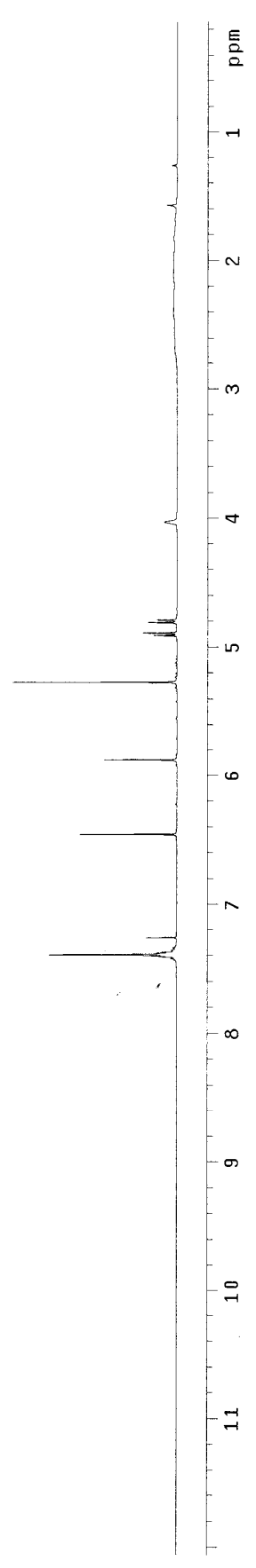




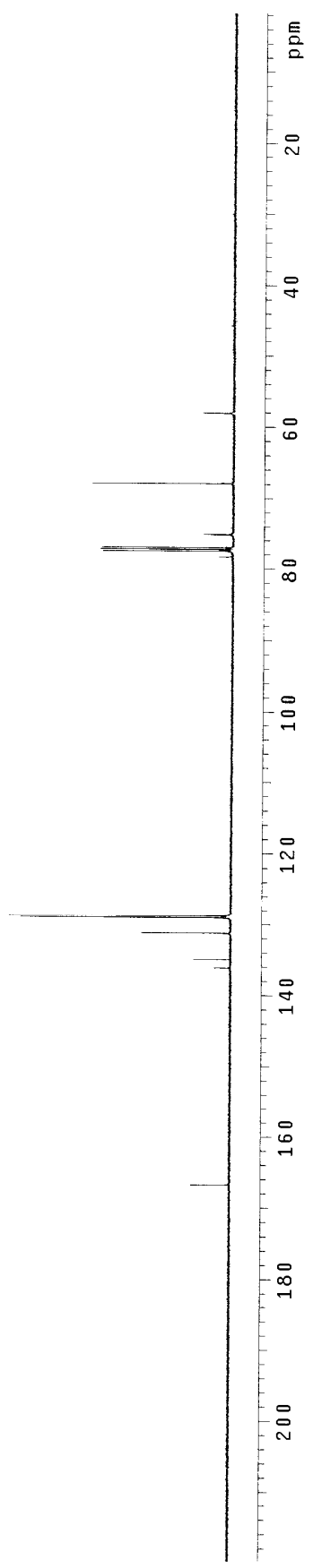




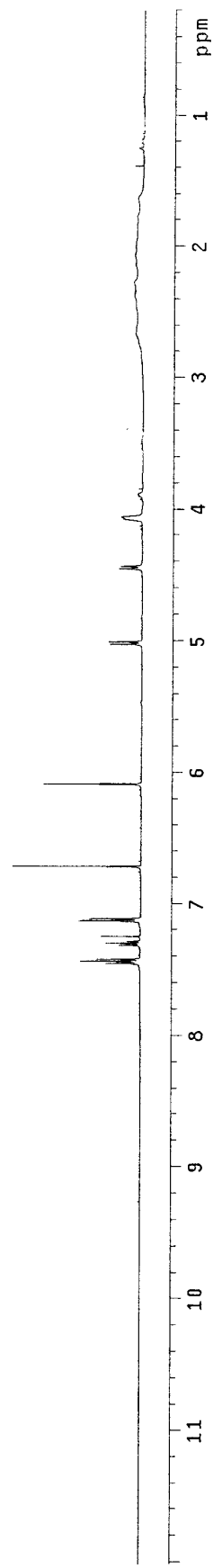




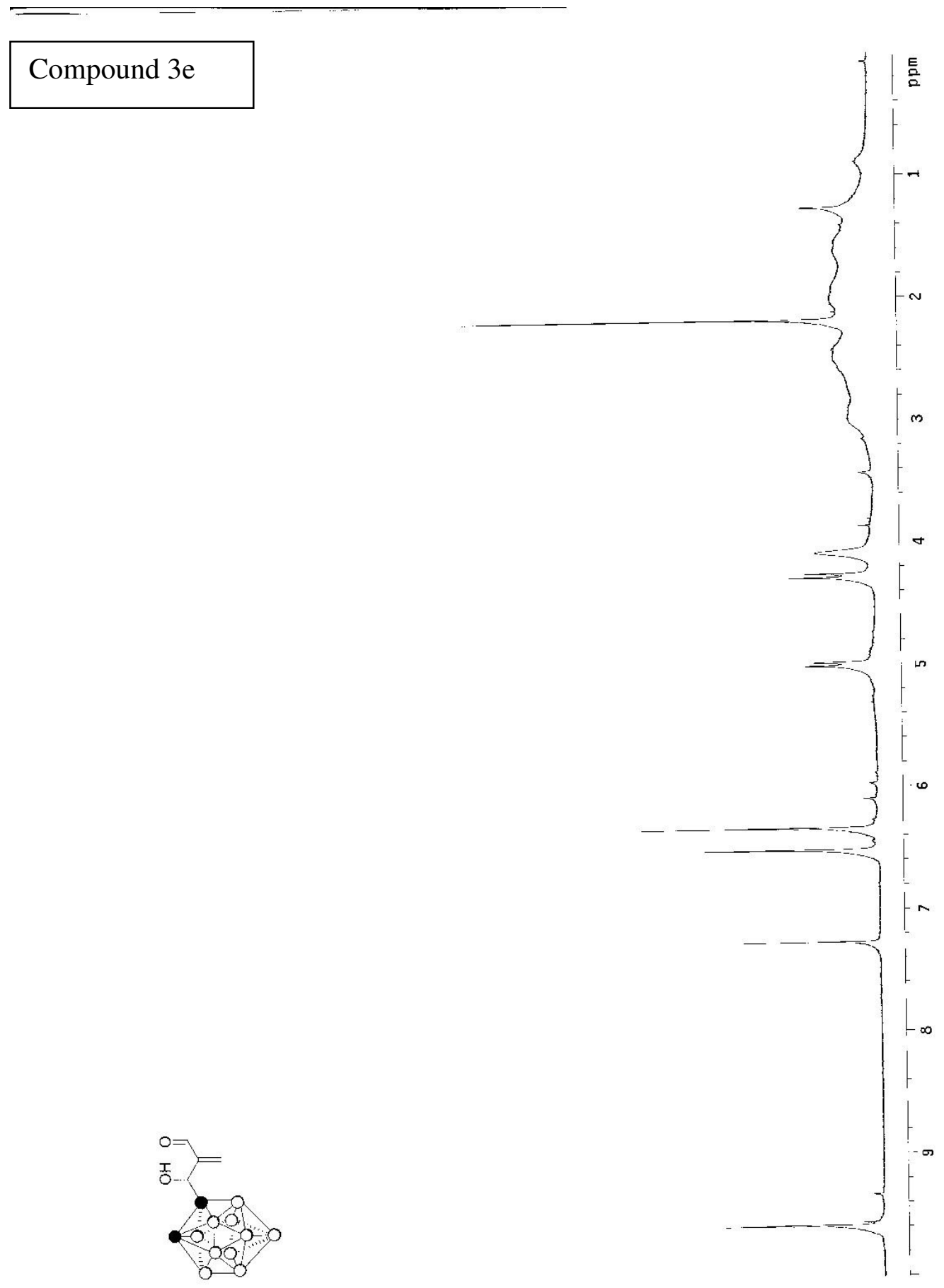




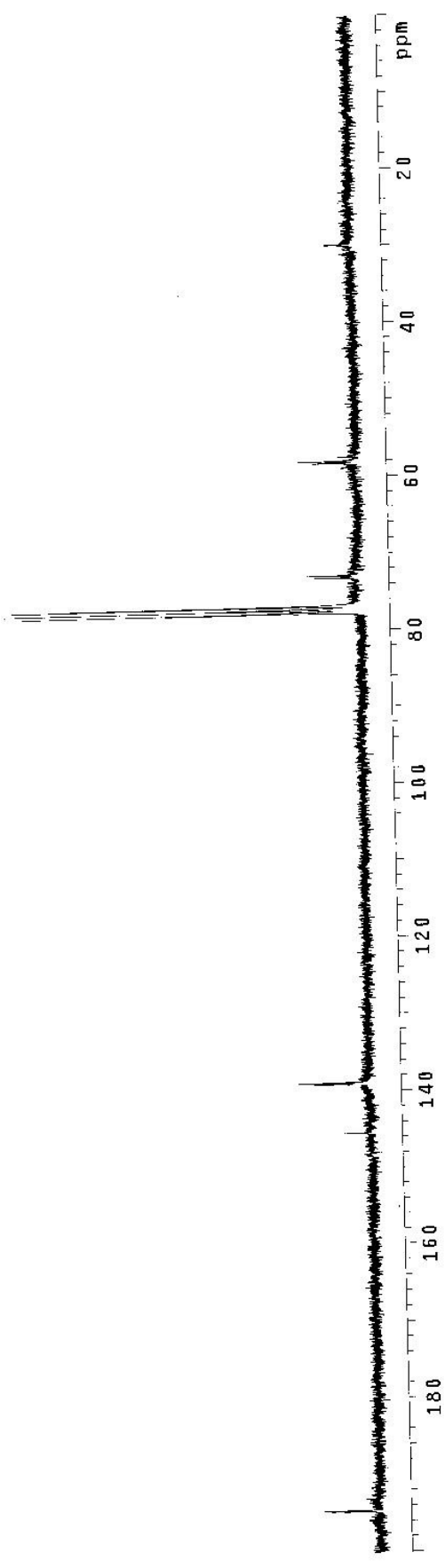


Compound $3 \mathrm{f}$

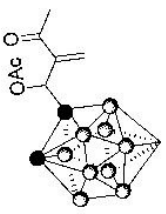

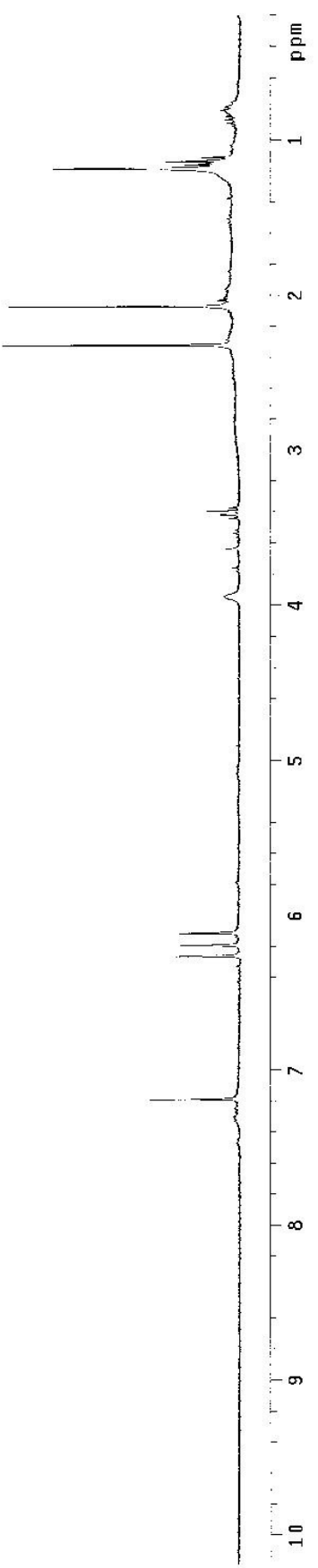




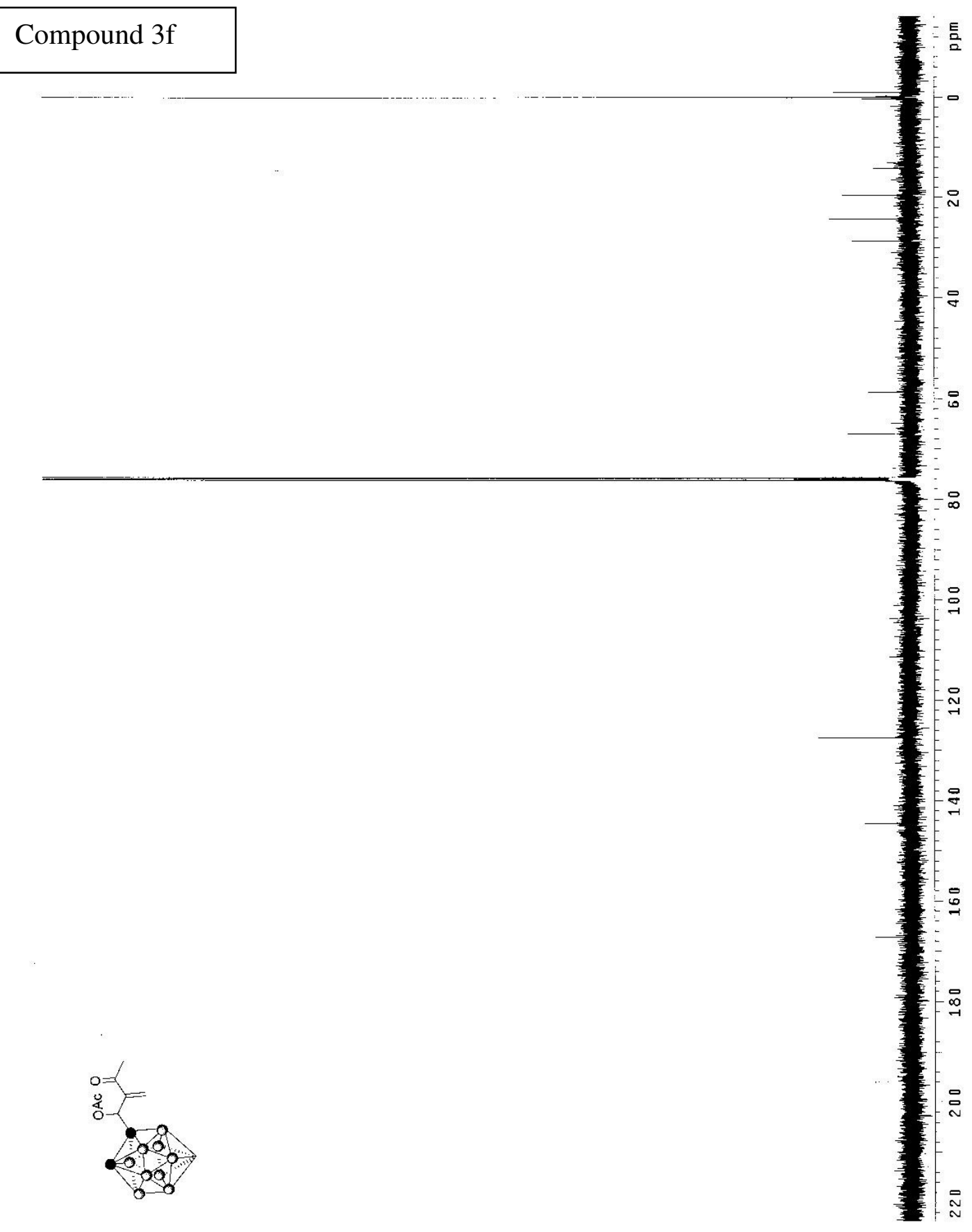


Compound 3g

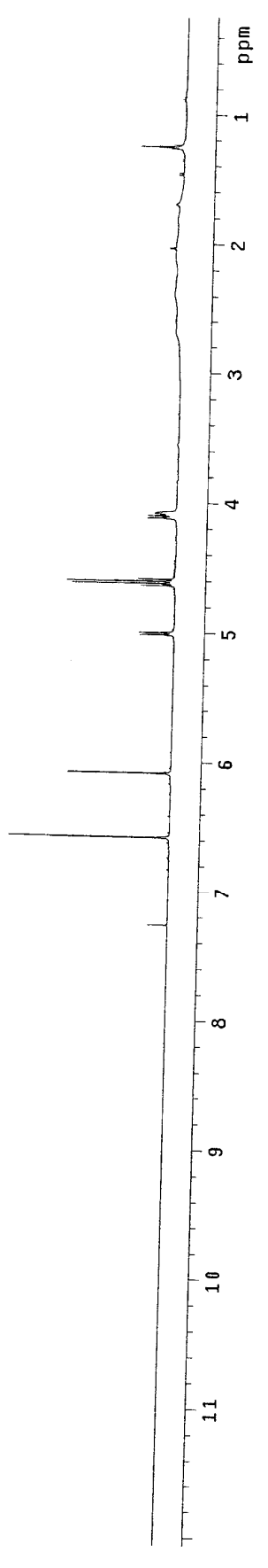




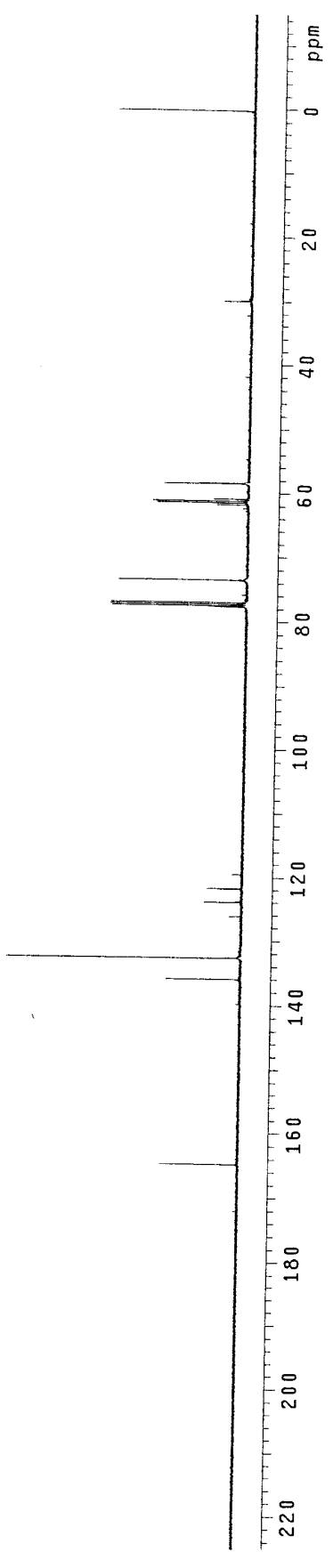




\section{Compound $3 \mathrm{~h}$}

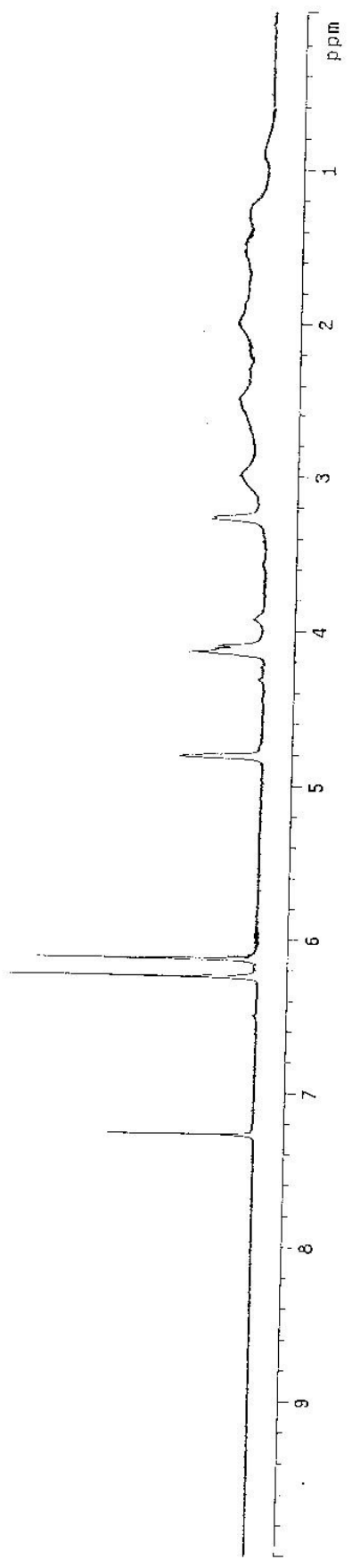




\section{Compound $3 \mathrm{~h}$}

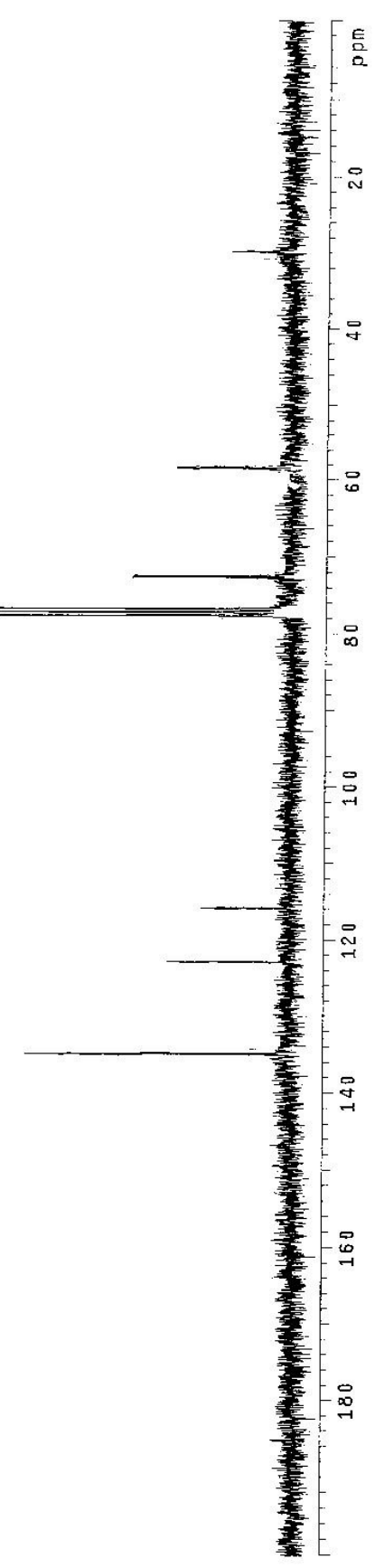




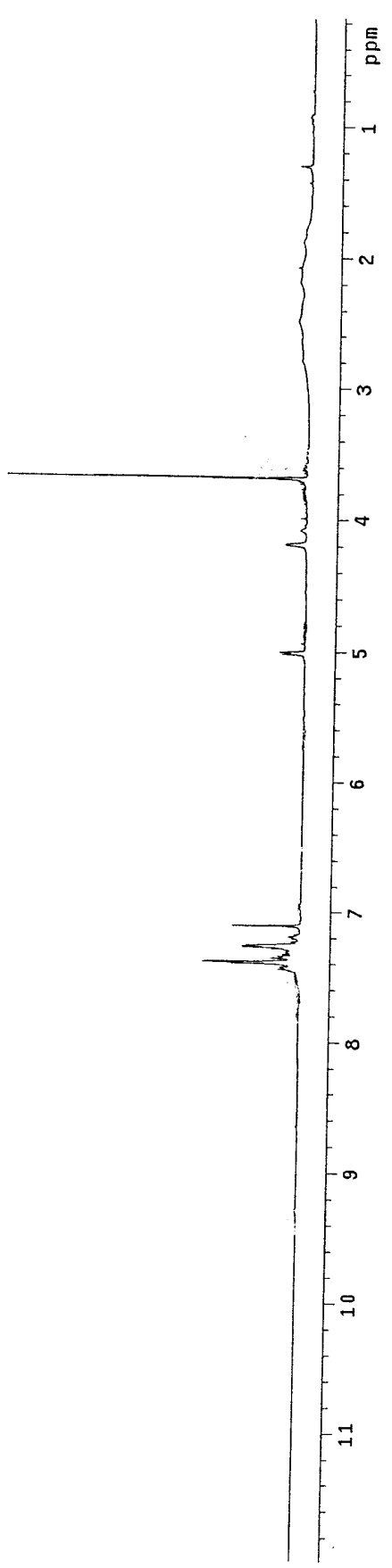


Compound $3 \mathrm{i}$

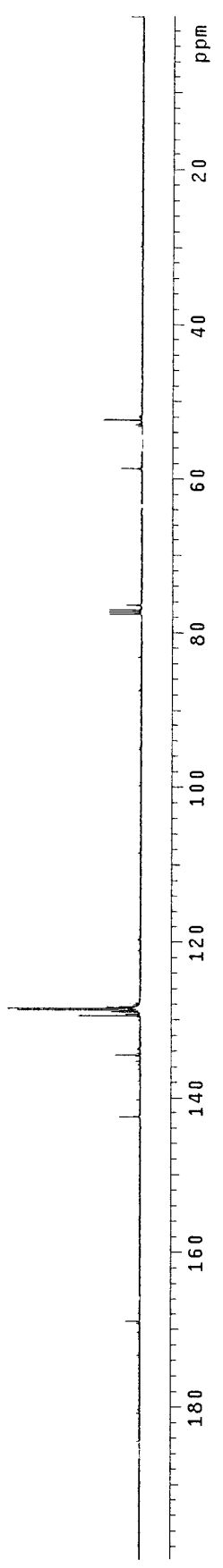


Compound 6

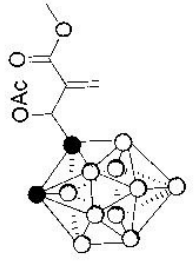

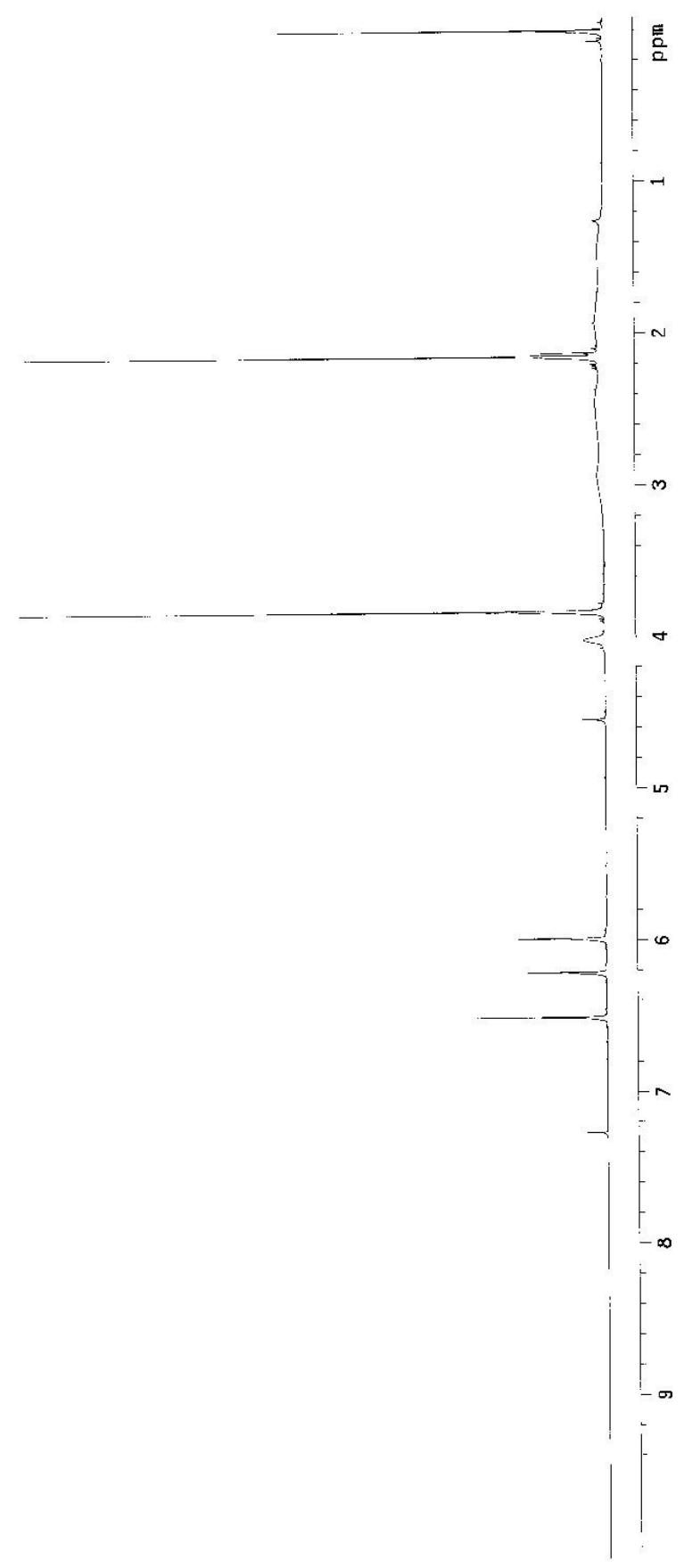




\section{Compound 6}

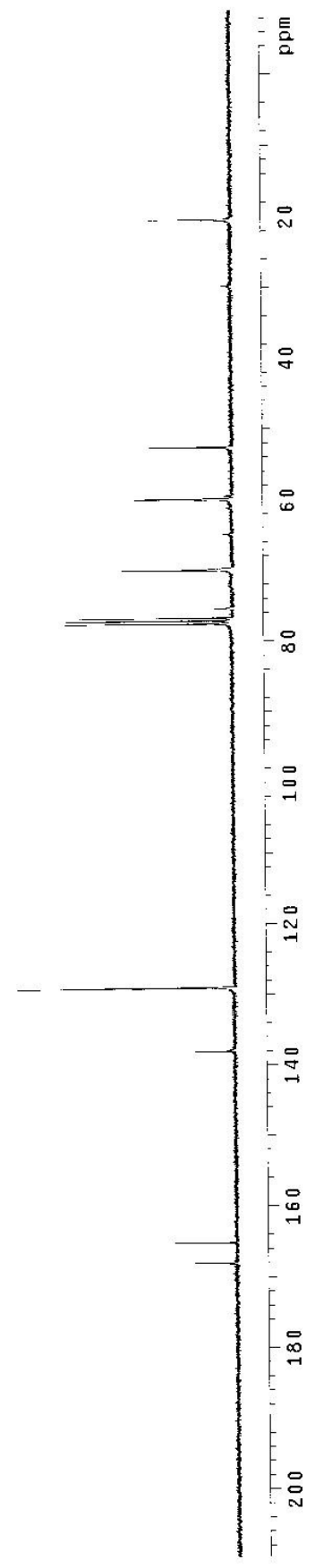


Compound 7

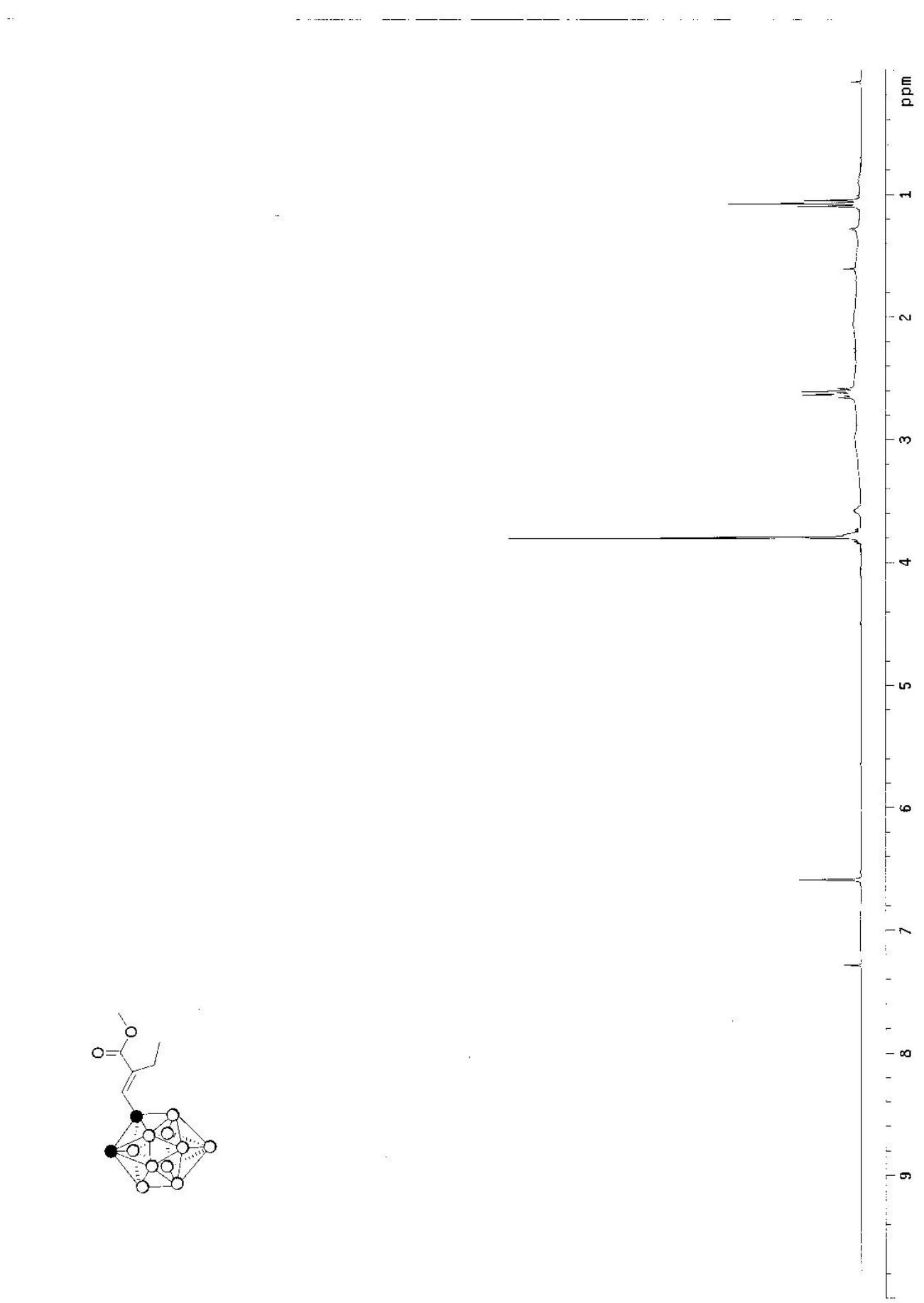


Compound 7

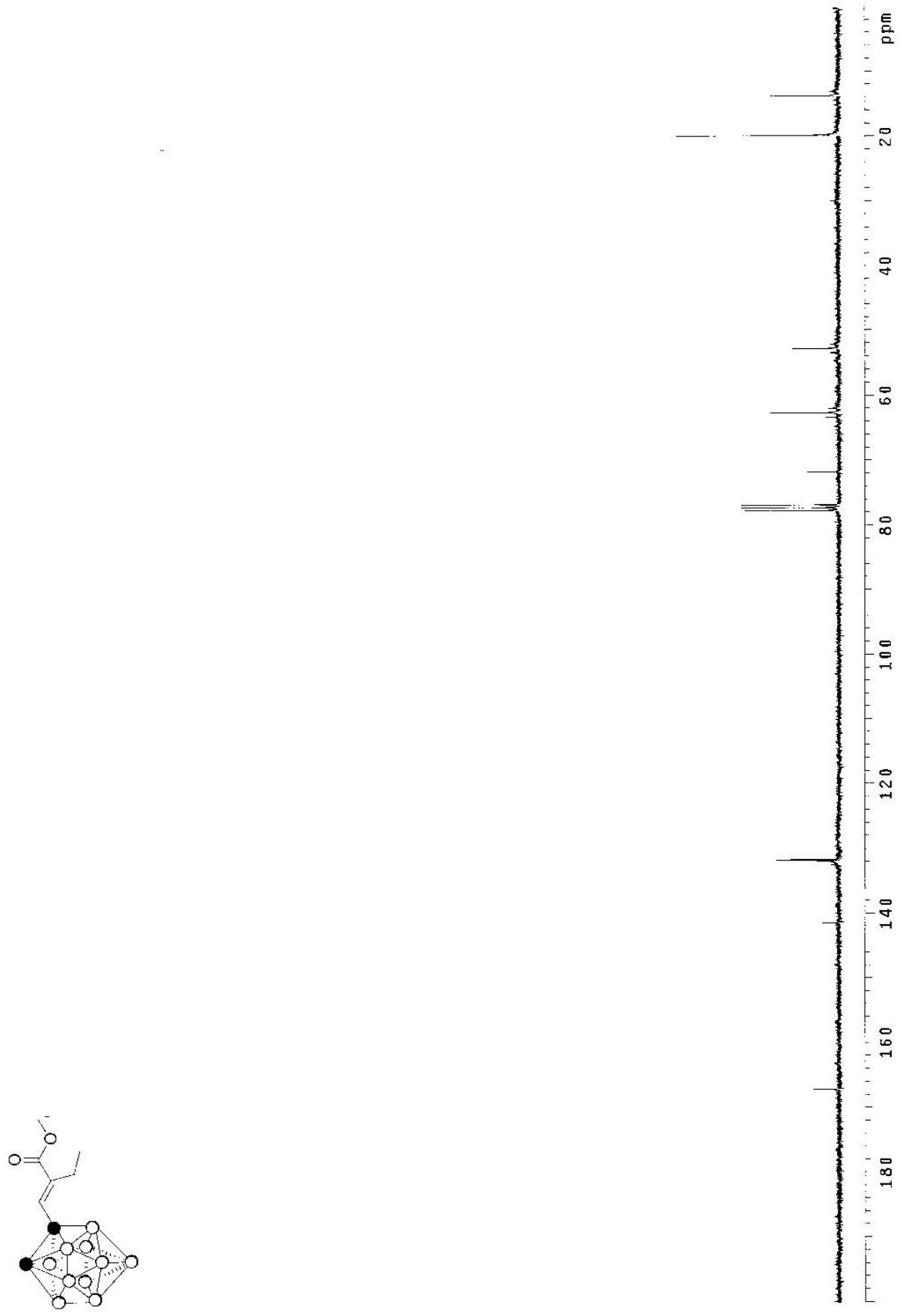


Compound 8

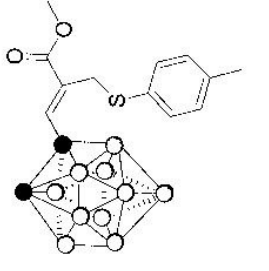

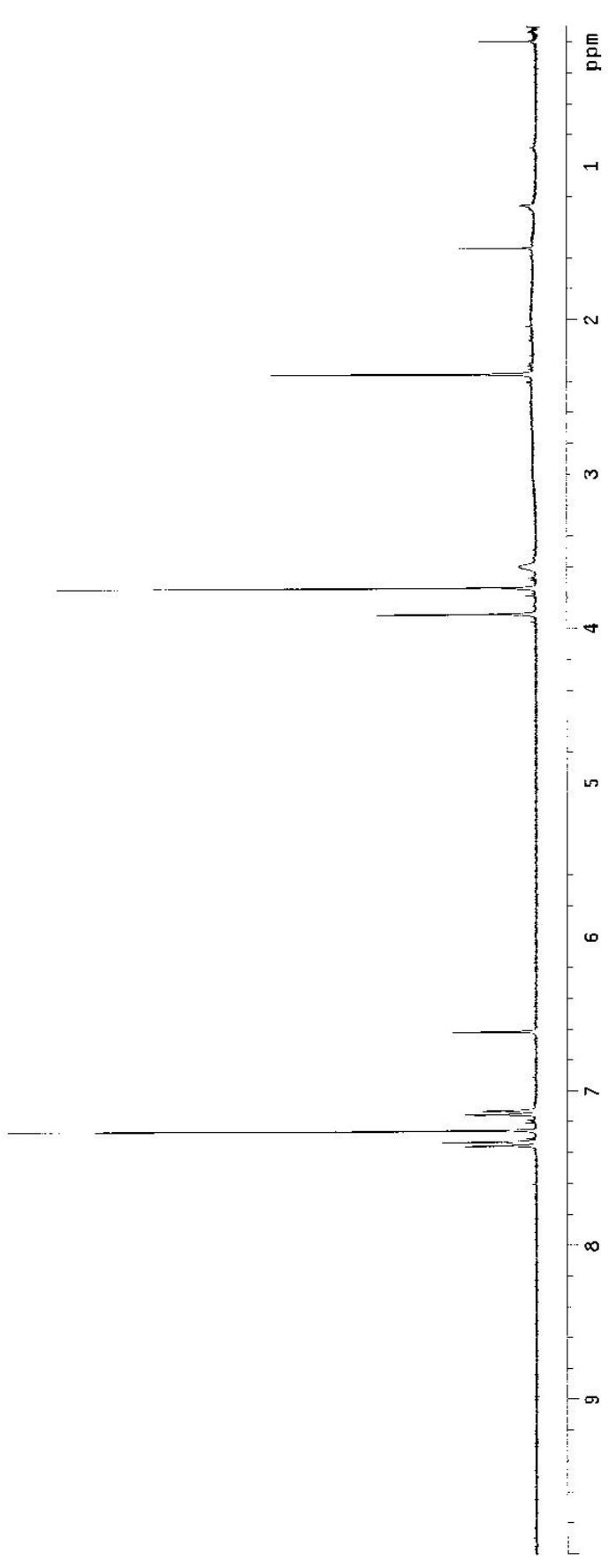




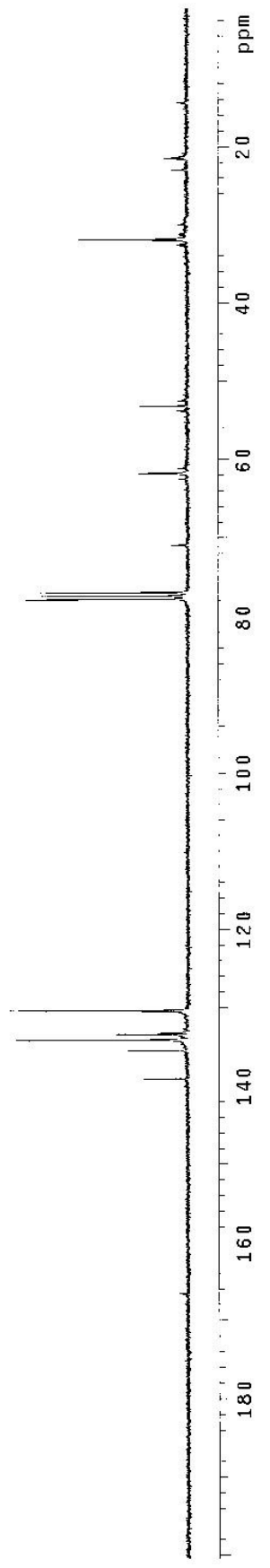




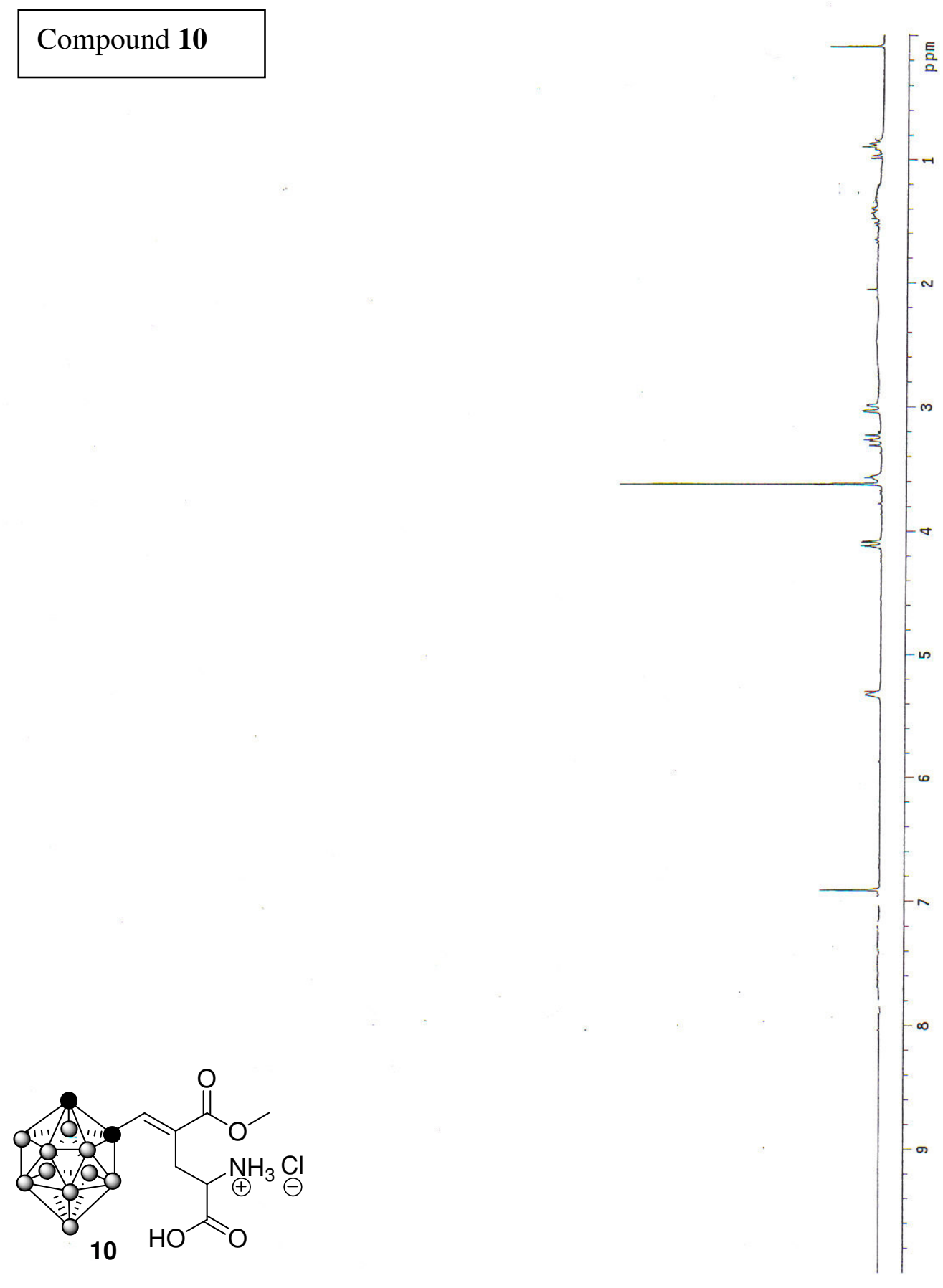




\section{Compound 10}
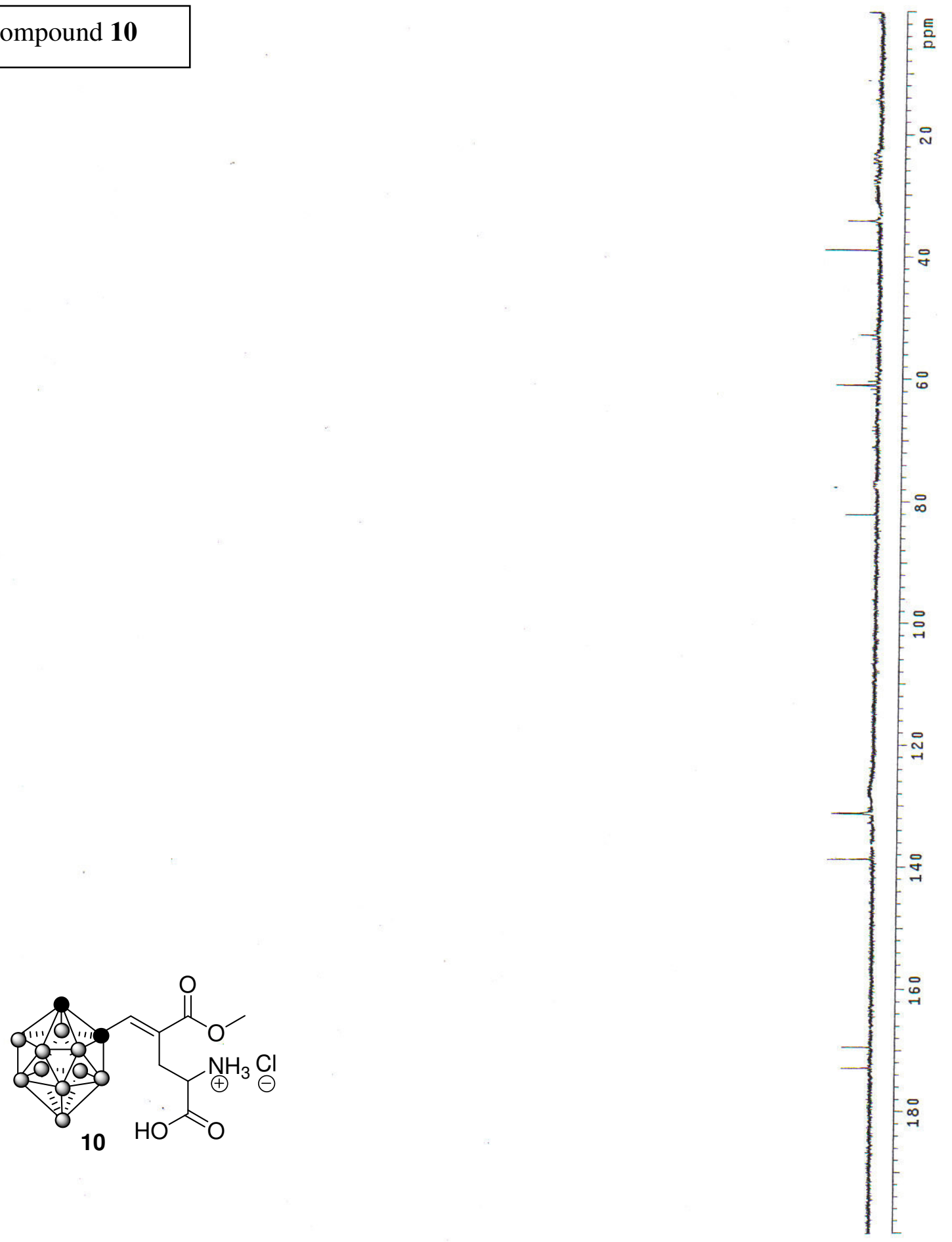